This manuscript is published in Journal of Urban History. Please also refer

to the final version via this link:

https://doi.org/10.1177/0096144220948813

\title{
New town planning as diplomatic planning: Scalar politics, British-Chinese relations, and Hong Kong*
}

\author{
Maurice Yip \\ Institute of Geography and Sustainability, University of Lausanne, Switzerland \\ KwanChung.Yip@unil.ch
}

Abstract

Tin Shui Wai new town in Hong Kong, known as the "city of sadness", has been narrated by the "Tin Shui Wai Myth" that attributes its urban problems to the planning failures after the colonial government rescued the developers, including a Chinese red capital, from a market slump in the early 1980s. This myth creates misunderstandings which confuse recent debates about new town development and regional integration with China. To debunk this myth, this article, based on archival research, analyses the scalar politics of new town planning and explains why the government decided to purchase the land and develop it in a partnership with these developers. It sheds new light on how the regional dynamics in South China after the economic reforms prompted China and Britain to react to the new town proposal at inter-connected and contested spatial scales, before the diplomatic negotiations about this British colony's future officially started.

\section{Keywords}

Hong Kong, Sino-British Negotiations, new town, regional integration, land lease, archival research

" Acknowledgements: The British national archival materials used in this research could not have been collected without the generous support from the Decoding Hong Kong's History Project. I thank Ha-Chi Yeung, Kin-Fung Tong, and KimChing Chan of Liber Research Community for their assistance. I also thank WingShing Tang, Anne Haila, Lachlan Barber, Jean Ruegg, Hendrikje Alpermann, TaiLok Lui, Ray Yep, Hyun-Bang Shin, Adrian J. Bailey, Chun Yang, and Hon-Chim Chiu for their comments and criticisms on my earlier writings and works from which this article originated. This article benefited from the feedback of the audience on its earlier version presented at the 9th Meeting of the East Asian Regional Conference in Alternative Geography (EARCAG) in South Korea in December 2018. 
While diplomacy is usually regarded as geopolitical relations in which state powers negotiate and interact at the international scale, such a perspective tends to be relatively abstract and overlooks the concrete significance of urban space to it. The historical account of the significant episodes in the transition period of Hong Kong from a British colony to a special administrative region in China mostly begins with two key moments: Governor Murray MacLehose's ice-breaking visit to Beijing in 1979, and the meeting between Deng Xiaoping and Margaret Thatcher which marked the beginning of Sino-British Negotiations in 1982. But what happened between these two moments is often neglected. In this article, I aim to not only discuss this gap period of diplomatic relations but also argue that there is a rarely discussed urban history engaging with scalar politics, with a particular focus on the planning and development of Tin Shui Wai (TSW) new town.

Being a home to nearly 300,000 people, TSW in the New Territories has been dubbed the "city of sadness" for its urban and social problems (Figure 1). The dominant narrative, which I call "Tin Shui Wai Myth", attributes these problems to urban planning failures after the government purchased back the land lease from a consortium that included a Chinese red capital developer, China Resources Company (CRC), to rescue it from a market slump in $1982^{1}$. A myth is not only a commonly believed but inaccurate narrative, but also, following Alan Smart, having "a mythical quality in the more positive sense" 2 . I argue this myth inaccurately implies the colonial government should solely bear the responsibility and neglects the current regime's interests involved, though the development benefited the Chinese state enterprise and facilitated regional integration with China. Consequently, this myth positively resonates with the authority of Hong Kong government under Chinese sovereignty to push forward new development and integration projects as long as proper planning procedures are claimed to be followed. This myth has not been challenged thus far and continues to confuse the debates. This obscures the wider implications of new town development processes and its potential for producing new knowledge about colonial urban governance in Hong Kong and the diplomatic relations between China and Britain.

\footnotetext{
1 "City of Sadness Fear for New Towns in New Territories," South China Morning Post, 5 July 2013.

2 Alan Smart, The Shek Kip Mei Myth: Squatters, Fires and Colonial Rule in Hong Kong, 1950 - 1963 (Hong Kong: Hong Kong University Press, 2006), 2.
} 
Figure 1: Map of Hong Kong showing the locations of Tin Shui Wai and other places mentioned in this article

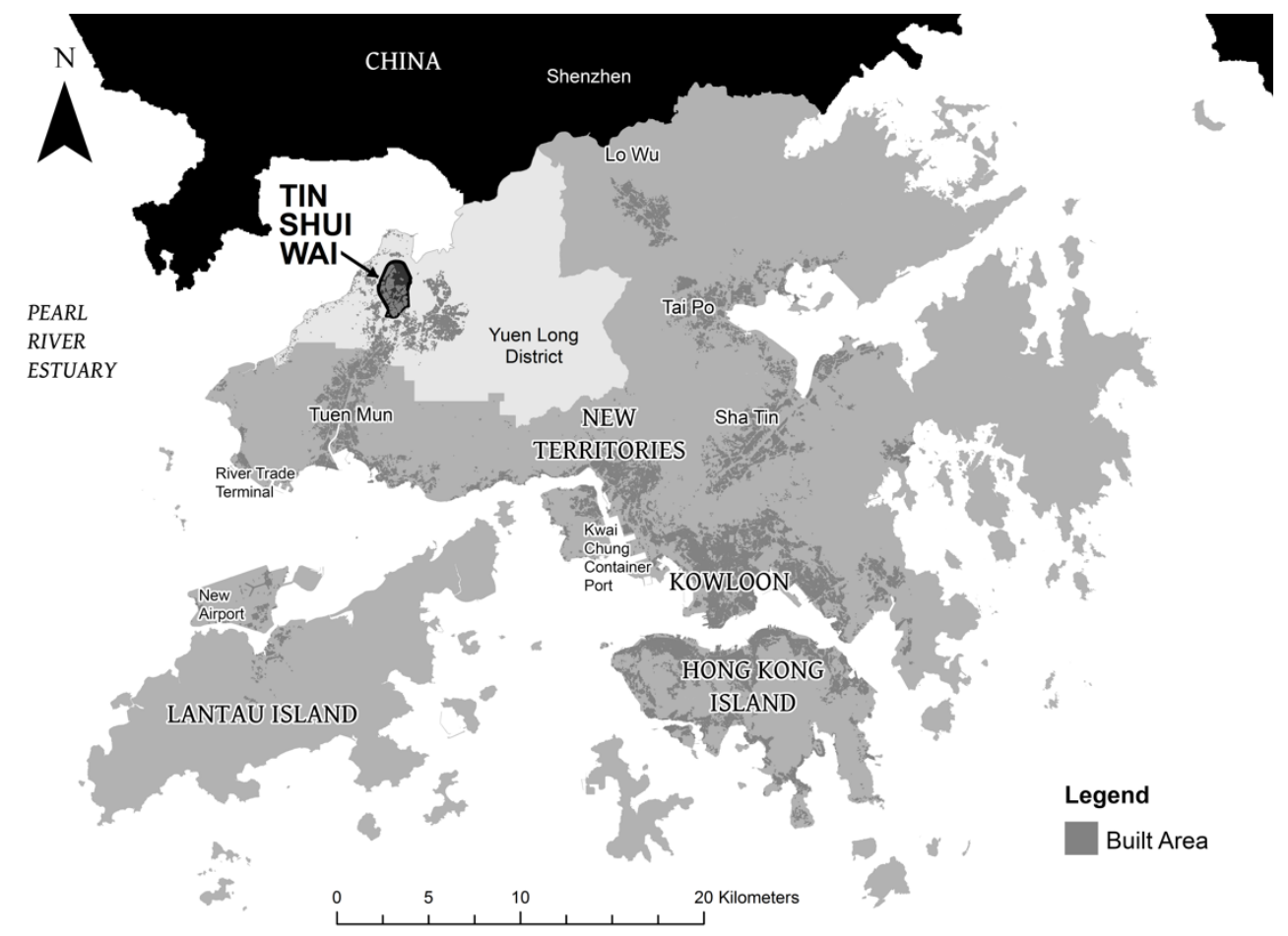

In this article, the timeframe under consideration is from the first development proposal in 1979 up to the making of its first master plan in 1983. Being leased to Britain, the land lease of the New Territories, the largest proportion of land in Hong Kong, was to expire in 1997, therefore the land leases of individual land lots were affected because of the leasehold land system. This legal problem of land gave rise to growing political and economic concerns after the Second World War, especially as time proceeded. As I will show, soon after MacLehose's 1979 Beijing visit, approving the red capital's new town proposal was believed to offer political advantages to the colonial authority in handling the pressing land lease problem for realizing governance goals. Red capital refers to the firms owned or controlled by the Chinese Communist Party and the Chinese state in Hong Kong, which emerged soon after the establishment of the Party in the 1920s, as the history of CRC can be traced back to the Party's investment in Hong Kong in the $1930 s^{3}$. These firms increasingly influence the local

\footnotetext{
${ }^{3}$ Xuexian Wu, Red China Resources Company [红色华润] (Beijing, China: Zhonghua Shuju, 2010).
} 
economy ${ }^{4}$. Following rounds of liaising and negotiation lasting almost three years, the colonial government publicly announced the TSW project in July 1982, two months before Deng and Thatcher, the leaders of the two states, met to initiate Sino-British negotiations. This process shows the issue at stake was neither a planning mistake nor an effort to rescue the developers; but a series of political calculations through which different actors at various geographical scales attempted to tease out how the two state powers would handle the question of Hong Kong's future. TSW was the first-ever new town planning exercise in Hong Kong that largely considered China's interests, revealing the ever-changing regional dynamics during the economic reform. These scalar politics were reflected in the plan-making process.

Scale, often taken-for-granted as "the nested hierarchy of bounded spaces of differing size" ${ }^{5}$, is embedded in the conventional imaginary of the colonial governance. Conventionally, the political order in colonial societies has been described as being "coercively imposed from above by the colonial authorities" ${ }^{6}$, implying a top-down model of power relations and assuming a passive role of the colonial government. However, viewing scale as a priori downplays the workings of power. One must beware of the danger of simplifying the historical account into a linear narrative of, for example, how London instructed MacLehose to work out the policies. As Yep suggests, we need to "go beyond the formal constitutional order in deciphering the relationship between London and the colony before 1997"7. Constitutional subordination does not imply the colony accepts all the instructions. Disagreements and debates between scales involve certain political contingencies ${ }^{8}$. A more contemporary understanding of scale considers it as

\footnotetext{
${ }^{4}$ Siu-Keung Cheung, "Reunification through Water and Food: The Other Battle for Lives and Bodies in China's Hong Kong Policy," The China Quarterly 220 (2014): 1012-32; Heidi Wang-Kaeding and Malte Philipp Kaeding, "Red Capital in Hong Kong," Asian Education and Development Studies 8, no. 2 (2019): 149-60.

${ }^{5}$ David Delaney and Helga Leitner, "The Political Construction of Scale," Political Geography 16, no. 2 (1997): 93-7.

${ }^{6}$ Siu-Kai Lau, Society and Politics in Hong Kong (Hong Kong: Chinese University Press, 1984), 5.

7 Ray Yep, "A Historical Perspective on Hong Kong Autonomy: Traditions of British Imperialism, Maritime Enclave and Contending Views of British Interest," in Hong Kong 20 Years after the Handover, ed. Brian C.H. Fong and Tai-Lok Lui (Springer, 2018), 231-54, 250.

8 Ray Yep, "The 1967 Riots in Hong Kong: The Diplomatic and Domestic Fronts of the Colonial Governor," The China Quarterly 193 (2008): 122-39.
} 
a political construction, being constituted by objects and processes as the territorial expression of evolving power relations ${ }^{9}$. Work on territoriality suggests that human adopts spatial strategies, such as territorial planning, to affect a geographical area for conditioning political spaces ${ }^{10}$. Scalar politics pays attention to the "strategic deployment of scale by various actors, movements and organisations" ${ }^{11}$. Empirical research, accordingly, looks into "the contested processes through which different scales are interconnected to each other via shifting power relations"12. In other words, it traces how various actors strategically associate a specific category of scale with the territorial and material relations. As Shin discusses, local-central state relations often engage with scalar politics. To realize certain goals, visions and plans, actors at the local scale would sometimes bypass the upper scale and directly jump to a more superior scale, without diminishing the nationstate scale ${ }^{13}$. Different actors negotiate with each other to test the limit of their power and plan for their desired future. In this article, I demonstrate TSW's engagement with scalar politics is reflected in the planning process, displaying how the local scale has been tied with multiple scales. Undoubtedly, TSW has its material conditions as it is bounded and fixed at a location in a physical and absolute view of land. The scales of TSW are, however, multiple. Because of the land lease problem, the development of TSW at the local scale has been tied with the international, national and regional scales during a political process to favor various interests.

To tell such a story, I used declassified archival materials from the British National Archives and Hong Kong Government Public Records Office to reconstruct the process of decision-making. It is noteworthy that, in the British Archives, correspondences relating to TSW were filed into folders on "Future of Hong Kong" maintained by the Foreign and

\footnotetext{
${ }^{9}$ Delaney and Leitner, "The Political Construction of Scale"; Danny MacKinnon, "Reconstructing Scale: Towards a New Scalar Politics," Progress in Human Geography 35, no. 1 (2011): 21-36.

${ }^{10}$ Robert Sack, Human Territoriality: Its Theory and History (Cambridge: Cambridge University Press, 1986).

${ }^{11}$ MacKinnon, "Reconstructing Scale", 32.

${ }^{12}$ Adrian J. Bailey, Suresh Canagarajah, Shanshan Lan and Devereux Gong Powers, "Scalar Politics, Language Ideologies, and the Sociolinguistics of Globalization among Transnational Korean Professionals in Hong Kong," Journal of Sociolinguistics 20, no. 3 (2016): 312-34, 315.

${ }^{13}$ Hyun Bang Shin, "Urban Spatial Restructuring, Event-led Development and Scalar Politics," Urban Studies 51, no. 14 (2014): 2961-2978.
} 
Commonwealth Office (FCO), instead of folders about urban development. This implies that TSW was considered extraordinarily significant to the colony's future. Recent archival studies on Hong Kong reject the taken-forgranted and fruitfully produce rigorous analyses, offering new insights into the colonial governance ${ }^{14}$. As the archived materials were intended for exclusive internal uses among government officials, they are informative for understanding the motivations undergirding decision-making processes. Nevertheless, they have an official nature and speak for Britain's interest, therefore in order to verify the accounts, wherever possible, I also compared them with the materials representing Chinese and Hong Kong voices, including CRC archives and politicians' memoirs. In this article, following the usual practice, the word "London" is used as a metonymy for the decision-makers and state leaders in the government of Britain, while "Beijing" refers to those of China.

This article proceeds in four sections. In the next section, I briefly introduce new town planning in Hong Kong which frames the urban context of TSW. Then, based on recent archival works, I revisit the political context in the 1970s, known as the "MacLehose Years", to clarify the political agenda of the colonial governance which is significant to understanding those decisions relating to TSW. These two sections are intentionally concise for making room to report my original research on the scalar politics of the TSW project in detail within the diplomatic context between Britain and China. I conclude this article by discussing the implications of this story in terms of advancing the understanding of Hong Kong's transition period and recent controversies, as well as the urban dimension of diplomacy which engages with scalar politics.

\footnotetext{
${ }^{14}$ Tai-lok Lui, “'Flying MPs' and Political Change in a Colonial Setting: Political Reform under MacLehose's Governorship of Hong Kong," in Civil Unrest and Governance in Hong Kong: Law and Order from Historical and Cultural Perspectives, ed. Michael H.K. Ng and John D Wong (London: Routledge, 2017), 76-96; Tai-Lok Lui, Wing Kai Stephen Chiu, and Ray Yep, "Introduction: The Long Transition," in Routledge Handbook of Contemporary Hong Kong, ed. Tai-Lok Lui, Wing Kai Stephen Chiu, and Ray Yep (Routledge, 2019), 1-29; Alan Smart and Tai-lok Lui, "Learning from Civil Unrest: State/Society Relations in Hong Kong before and after the 1967 Disturbances," in May Days in Hong Kong: Riot and Emergency in 1967, ed. Robert Bickers and Ray Yep (Hong Kong University Press, 2009), 145-60; Ray Yep, "A Historical Perspective on Hong Kong Autonomy"; Ray Yep and Tai-Lok Lui, "Revisiting the Golden Era of MacLehose and the Dynamics of Social Reforms," China Information 24, no. 3 (2010): 249-72.
} 


\section{Tin Shui Wai Myth}

Except for one church site, leasehold is the only land tenure in Hong Kong since the 1840 s $^{15}$. During the Nineteenth Century, the Qing Empire perpetually ceded the Island and Kowloon and leased the New Territories, for 99 years starting from 1898, to Britain. The colonial government, as the landlord, utilized this same legal mechanism to govern the whole territory ${ }^{16}$. After the Second World War, especially after the 1970s, the development of new towns decentralized the rapidly growing population from the ceded area to the leased area ${ }^{17}$. It was almost the only practical planning solution to the population problem, but the planning and development process was not without difficulties. The colonial government needed to deal with the customary land practices in indigenous villages, meaning that the land disputes were subject to not only the leasehold tenure but also consents from all village managers and the cultural traditions ${ }^{18}$. Another difficulty is the financial problem because developing new towns is a huge commitment in the long run, including the cost of land reclamation and urban infrastructure. Yet, the outcome of these planning exercises is seemingly satisfactory, as most of the new towns are planned with appropriate land use zoning and developed "as self-sufficient integrated communities, alleviating the burden of the core urban districts" ${ }^{19}$. It is a popular discourse that residents in new towns, such as Sha Tin and Tai Po, are proud of their local identity, and these towns are usually modelled as successful planning cases. On the contrary, TSW is described as the failed new town. During the early 2000s, several family tragedies in TSW drew public attention to its

\footnotetext{
${ }^{15}$ Say Hak Goo and Alice Lee, Land Law in Hong Kong (Hong Kong: LexisNexis, 2015).

${ }^{16}$ Sui-Wai Cheung, "Landlords, Squatters, and Tenants: Fundamental Concepts of Land Administration in Early Colonial Hong Kong," in Colonial Administration and Land Reform in East Asia, ed. Sui-Wai Cheung (Routledge, 2017), 21-36.

${ }^{17}$ Pui-Yin Ho, Making Hong Kong: A History of Its Urban Development (Northampton, MA: Edward Elgar, 2018), 190.

${ }^{18}$ James Hayes, Tsuen Wan: Growth of a 'New Town' and Its People (New York: Oxford, 1993).

${ }^{19}$ Ho, Making Hong Kong, 275.
} 
urban social problems ${ }^{20}$. The government officials labelled it as "city of sadness" ${ }^{21}$ and sought solutions by providing more social supports and conducting planning reviews.

This exceptional case of a "failed" new town has attracted the interests of researchers who identified two major problems with its urban planning. Firstly, spatial mismatch and lack of community facilities are considered as consequences of technical planning failures. Remotely located in the north-western corner of the New Territories, TSW's low proximity to urban core and major employment centers made daily commuting costly and time-consuming ${ }^{22}$. Residential land use dominates one-fourth of area, having an above-average ratio of public housing among the new towns ${ }^{23}$. This problematic explanation assumes urban planning as a mere technical activity, and planning failure could be avoided once a scientific and comprehensive procedure is followed, while neglecting that urban planning is a process of dealing with territorial politics. Secondly, the proliferation of unaffordable retail businesses controlled by private developers, and the lack of job opportunities, are regarded as outcomes of a deal between the colonial government and the consortium in 1982, as a government-commissioned analysis conducted by academics ${ }^{24}$ and the journalistic reports ${ }^{25}$ suggested.

${ }^{20}$ Bidisha Banerjee, "Looking beyond 'Buildings of Chrome and Glass': Hong Kong's 'Uncanny Postcoloniality' in Photographs of Tin Shui Wai," Visual Studies 32, no. 1 (2017): 60-69; Kwok Kin Fung and Suet Lin Hung, "Strengthening a Community of Poverty in an Affluent Society: Strategies to Build Social Capital in Tin Shui Wai North in Hong Kong," Community Development Journal 49, no. 3 (2014): 441-57; ChoYam Joseph Lau, "The Influence of Suburbanization on the Access to Employment of Workers in the New Towns: A Case Study of Tin Shui Wai, Hong Kong," Habitat International 34, no. 1 (2010): 38-45; Tina L. Rochelle, "Diversity and Trust in Hong Kong: An Examination of Tin Shui Wai, Hong Kong's 'City of Sadness,"' Social Indicators Research 120, no. 2 (2015): 437-54.

21 "Carrie Lam: Tin Shui Wai is a City of Sadness" (trans.), Ming Pao, 9 July 2006.

${ }^{22} \mathrm{Lau}$, "The Influence of Suburbanization on the Access to Employment of Workers in the New Towns"; Hung Wong, "Quality of Life of Poor People Living in Remote Areas in Hong Kong," Social Indicators Research 100, no. 3 (2011): 435-50.

${ }^{23}$ Tin Shui Wai Outline Zoning Plan (S/TSW/13), gazetted on 26 May 2017 .

${ }^{24}$ Chi-Kwong Law et al., "A Study on the Tin Shui Wai New Town: The Planning and Development Process" (Hong Kong: Planning Department, 2009). This study was part of the North East New Territories New Development Areas Planning Study in the late 2000s.

25 “Colonial Deal Built 'City of Sadness'," South China Morning Post, 6 December 2010. 
This accused the colonial government of favoring the business sector, without contextualizing planning and deal-making processes.

Yet, these findings leave out the historical geography of the land of TSW and the two state powers - China and Britain. Virtually no attempt is made to explore why and how the agreement was reached, except WingShing Tang's work ${ }^{26}$. Undoubtedly, Tang has made an enormous long-term contribution that called for critical reading of new town planning in Hong Kong. But I argue that his argument which was articulated in mass media has also contributed to creating the myth. Tang argues that the colonial government rescued a failed private investment to secure the land development regime of Hong Kong. The conventional imaginaries about the colonial governance, that the colonial government at the local scale has a relatively passive and minor role in diplomatic negotiations, limited his analysis, which will be addressed through the lens of scalar politics in this article. Of immediate interest, his analysis relies on an earlier work by Roger Bristow who asserted that the colonial government inevitably decided to rescue this project from the market slump ${ }^{27}$. Bristow offered an analysis quickly in the 1980s when TSW was still undergoing sorts of controversies. His conclusions made sense for him, provided that he could, at the time of writing, only collect information from sources at his reach. But the narratives from this, with the absence of the two state powers in the discussion, became mythical.

In examining the history of new towns, Bristow correctly documented that the government bought the developers' landholding in TSW and developed it together in 1982. However, two problems are noteworthy. The first is the location. He asserted TSW was in the "general area" of the development areas recommended by the Special Committee of Land Production in $1977^{28}$. Although the succeeding policy and academic

\footnotetext{
${ }^{26}$ Wing-Shing Tang, Tin Shui Wai: Is It a Matter of Inadequate Provision?, Occasional Paper Series 82, Hong Kong: The Centre for China Urban and Regional Studies, Hong Kong Baptist University, 2008; Wing-Shing Tang, A Historical-Geographical Perspective of the Social Problems in Tin Shui Wai New Town, Hong Kong [香港天 水围新市镇社会问题的历史地理观], China Ancient City [中国名城] 7, 2009: 19-25. They stimulated discussions about TSW and urban planning in Hong Kong, especially during the "Land Debate" in 2018 on mass media including Ming Pao, HK01, the Stand News, and In-media, to name a few.

${ }^{27}$ Roger Bristow, Hong Kong's New Towns: A Selective Review (New York: Oxford University Press, 1989).

${ }^{28}$ Ibid., 215.
} 
studies followed Bristow's account, a careful reading of the report and its map undoubtedly reveals the area in the south to TSW was instead recommended $^{29}$. This is important for explaining the developers' decisionmaking, as will be demonstrated. The second problem is his unjustified assertations about the land resumption. Bristow quoted some reports to assert that the government originally proposed to postpone the TSW project due to other infrastructural commitments including the new airport. Here, yet, this was only the advisory committee's suggestion. Bristow then attributed the change of government's decision, from project postponement to land resumption, to the property market downturn, hence "the Government was thus forced by political considerations to intervene" 30 . Bristow did not give any evidence here. He continued, "the consortium resisted this initial reaction, arguing that on viability grounds it required all or nothing for the scheme", but he could not explain, if the consortium was facing difficulties, why it was able to have the bargaining power to negotiate with the government. Bristow then wrote ${ }^{31}$,

[t]he property slump of that year pressurized the developers to settle, and as the Government knew that serious negotiations with China on the future of Hong Kong were about to get under way, they were already aware that any collapse of the Tin Shui Wai scheme, given that Chinese involvement in it, would be highly and seriously embarrassing.

But, once again, no evidence was given. This is how the partial and mistaken myth was made. Then, why did MacLehose's government decide to resume TSW and develop it in a partnership with the consortium? Answering this question has to begin with clarifications about colonial governance and its ultimate goal, which allow us to better understand the political reasons behind the decision.

\section{Revisiting the "MacLehose Years" through archives}

People termed the 1970 s as the "MacLehose Years" to give credit to Governor MacLehose, who entered the office in 1971 and left the colony in 1982, for initiating many reforms. MacLehose received loud applause for bringing sudden changes as widely perceived. This stereotypical imaginary persisted until the recent archival research told another story. The archives

${ }^{29}$ Special Committee on Land Production, "Report of the Special Committee on Land Production" (Hong Kong: Government Printer, 1977).

30 Bristow, Hong Kong's New Towns, 219.

${ }^{31}$ Ibid. 
show the Governor, who was left with the last word in decision-making in the British coloniality ${ }^{32}$, did not resolute as what we commonly think ${ }^{33}$.

Above all, the political agenda throughout MacLehose's governorship was to widen the gap between Hong Kong and China by transforming the colony to an advanced status which China could hardly absorb, and which can only be governed by Britain to sustain its long-term interest ${ }^{34}$. It was because, during the re-organization of world order after the Second World War, the land lease problem concerned Britain who desired to safeguard this colony for their interest in Far East. This question was even urgently pressing when MacLehose was appointed. As an experienced diplomat, he continued the on-going tasks with his "government in a hurry" 35 for approaching a special status of Hong Kong after 1997. MacLehose had repeatedly communicated with London about this ambition during his tenure. In his view, advancing Hong Kong into a model city was the only way for Britain to keep Hong Kong because this colony was not defensible if China decided to take it violently, as what Britain had learnt from the pro-Communist-China 1967 riots against the British colonial rule ${ }^{36}$. Similarly, Lui also found the China factor had put forward the longer-term planning and social reforms, but it was also a political constraint ${ }^{37}$. Maintaining the equilibrium in Hong Kong from which both Britain and China could gain was important for MacLehose.

For realizing this governance goal of his tenure, MacLehose launched a ten-year housing programme in 1972 to construct public works that are

\footnotetext{
${ }^{32}$ Yep and Lui, "Revisiting the Golden Era of MacLehose and the Dynamics of Social Reforms."

${ }^{33}$ Lui, "'Flying MPs' and Political Change in a Colonial Setting”; Smart and Lui, "Learning from Civil Unrest"; Ray Yep, "The Crusade against Corruption in Hong Kong in the 1970s: Governor MacLehose as a Zealous Reformer or Reluctant Hero?," China Information 27, no. 2 (2013): 197-221.

${ }^{34}$ Pang-kwong Li, Governing Hong Kong [管治香港] (Hong Kong: Oxford University Press, 2012); Smart and Lui, "Learning from Civil Unrest"; Yep and Lui, "Revisiting the Golden Era of MacLehose and the Dynamics of Social Reforms"; Yep, "A Historical Perspective on Hong Kong Autonomy."

${ }^{35}$ John Carroll, A Concise History of Hong Kong (Lanham: Rowman \& Littlefield, 2007); Smart and Lui, "Learning from Civil Unrest"; Lui, "Flying MPs' and Political Change in a Colonial Setting."

${ }^{36} \mathrm{Li}$, Governing Hong Kong, 22.

${ }^{37}$ Lui, “'Flying MPs' and Political Change in a Colonial Setting."
} 
essential to modern life ${ }^{38}$. Constructing new towns was crucial to achieving the aim of accommodating 1.8 million people in public housing estates in ten years, but two major uncertainties might hinder the progress. Firstly, the demands for urban infrastructure posed a public finance challenge. The second uncertainty was the land lease problem. Bankers worried the 15-year mortgage of real estate could not go beyond 1997, and developers were afraid that their land leases could not be renewed upon the expiry ${ }^{39}$. Meanwhile, the financialization of the real estate market, that enabled the local capital to compete with the British capital in the game, created land demand. To entertain its governing partners in the business sector, MacLehose's government established the Special Committee on Land Production in 1977 to conduct a land study which excluded land which might involve clearances, the Lantau, Hong Kong Island and country parks ${ }^{40}$. That means, only the potentials of developing New Territories were studied ${ }^{41}$. But developing the New Territories was concerned with the land lease problem, urging MacLehose to raise it to China.

Meanwhile, a series of changes happened in China - the death of Mao Zedong, the end of Cultural Revolution, the rise of Deng Xiaoping and the announcement of economic reform and modernization. MacLehose maintained a friendly distance with China and recognized the Xinhua News Agency Hong Kong Branch as an unofficial Chinese government representative in this colony. In 1978, he raised the land lease problem to Wang Kuang, Xinhua's new director; but Beijing decided to postpone the answer due to the principle of "taking long-term views and taking full advantage" 42 . Yet, the Chinese leaders invited MacLehose to visit Beijing for seeking support from Hong Kong to their economic reform. London and MacLehose considered it as an opportunity to discuss the land lease problem. Being the British Ambassador to China, Percy Cradock wrote in his memoir that he was personally not particularly optimistic about the outcome, but MacLehose's government had a contrasting view by suggesting that "the

\footnotetext{
3818 October 1972, Hong Kong Hansard.

${ }^{39}$ Bangyan Feng, A Century of Hong Kong Real Estate Development [香港地產業百年] (Hong Kong: Joint Publishing, 2001).

4020 April 1977, Hong Kong Hansard.

${ }^{41}$ Special Committee on Land Production, "Report of the Special Committee on Land Production."

${ }^{42}$ Ping Lu, Ping Lu's Oral History about the Reunification of Hong Kong [魯平口述香港回 歸] (Hong Kong: Joint Publishing, 2009).
} 
Chinese were concerned primarily with economic reform and that nationalist considerations came second" 43 . This view from the man-on-thespot framed the tactics of the British side ${ }^{44}$.

During their meeting on 29 March 1979, although MacLehose would like to mention to Deng the question of Hong Kong's future, it was Deng who first raised this question ${ }^{45}$. Deng told MacLehose that he hoped Britain not to raise the problem too early and he had no policy about Hong Kong yet, but whether or not Hong Kong would maintain the status quo or be resumed by China, there would be special policies so the investors can rest their hearts at ease ${ }^{46}$. In fact, one must note that, on the contrary to some analyses ${ }^{47}$, Beijing had no ideas about handling the question of Hong Kong, and the preliminary proposal of the basic policies only began to emerge in mid-1982, according to various memoirs ${ }^{48}$.

Immediately, MacLehose responded to Deng that sovereignty was the long-term matter for the Chinese and British governments, but "the question of New Territories leases was one which could not be dealt with by general assurances and would not wait" ${ }^{49}$. MacLehose proposed to

${ }^{43}$ Percy Cradock, Experiences of China (London: John Murray, 1994), 166.

${ }^{44}$ Admittedly, there were internal debates in Britain on this question which lasted for decades. Despite Cradock's idea that it was the other way around and the nationalist considerations were prioritized in the Chinese mind, similar discussions were evidenced by their review of 1967 riots in which London recognized China's emphasis on nationalism and saw that the Communist Chinese government would not allow any extension of the lease of Hong Kong in the late 1960s. See Yep and Lui, "Revisiting the Golden Era of MacLehose and the Dynamics of Social Reforms", 120. But, as discussed here, it was evident that Britain tended to bet on playing the treaties card.

4530 March 1979, Cradock to FCO, FCO40/1058: Future of Hong Kong: New Territories leases (Part A). 1979; Sze-Yuen Chung, Hong Kong's Journey to Reunification: Memoirs of Sze-Yuen Chung (Hong Kong: The Chinese University of Hong Kong, 2001), 31.

${ }^{46}$ Ibid. See also Wen-fang Huang, China's Resumption of Sovereignty over Hong Kong (Hong Kong: David C. Lam Institute for East-West Studies, Hong Kong Baptist University, 1997); Lu, Ping Lu's Oral History about the Reunification of Hong Kong.

${ }^{47}$ Tang, "Tin Shui Wai".

${ }^{48}$ Huang, China's Resumption of Sovereignty over Hong Kong; Lu, Ping Lu's Oral History about the Reunification of Hong Kong; Jiatun Xu, Memoirs of Jiatun Xu on Hong Kong [許家 屯香港回憶錄] (Taipei, Taiwan: Linking Publishing, 1993); Lui, Chiu, and Yep, "Introduction: The Long Transition."

499 April 1979, David Owen to Prime Minister, 'Hong Kong: New Territories Leases', FCO40/1058. 
replace the expiry date of the leases with the phrase "as long as Britain administered the New Territories" because this was a very concrete issue in the legal technicalities of land lease in Hong Kong. As Cradock wrote, this idea of blurring the 1997 deadline came "either from the Governor or from one of his advisers" and was to be presented as "a technical and commercial matter, as a means of sustaining investment" ${ }^{50}$. Here, Deng "appeared to accept that all that was proposed was the removal of the terminal date in leases, and that this required no Chinese action and did not conflict with the Chinese position" ${ }^{51}$. Deng's response was ambiguous as it meant neither agree nor disagree. MacLehose subsequently explained the same proposal to other key cadres including Huang Hua, the Foreign Minister, and Liao Chengzhih, who had responsibility for Hong Kong affairs. No one endorsed but also no rejection. Britain found that the Chinese leadership simply did not understand what the land lease problem was, as David Owen reported "Deng evidently found it difficult to grasp the English legal concepts involved" 52 . This is convincing because, otherwise, the Chinese leadership had no need to invite the professionals from Hong Kong to advise on the reform of land law in the 1980 s $^{53}$. Interestingly, as Carroll writes, "MacLehose returned to Hong Kong relieved and optimistic" ${ }^{44}$. Cradock recalled in his memoir that, after the Beijing visit, "[t]he Hong Kong government still hoped that economic realities would press upon the Chinese and bring them round to a more co-operative attitude" ${ }^{55}$. Lui's archival research reports a similar observation that, as both the British Labour Government, until May 1979, and the succeeding Conservative Government had not yet thought about political transition which was later only triggered by the Sino-British negotiations, MacLehose was confident that Britain can undoubtedly rely on the three treaties to continue the colonial governance ${ }^{56}$.

In November 1979, MacLehose and Wang Kuang met. MacLehose still remained his optimism and expressed his willingness to contribute

${ }^{50}$ Cradock, Experiences of China, 165.

${ }^{51}$ Ibid.

${ }^{52}$ Ibid.

${ }^{53}$ Maurice Yip, "Hong Kong as a Property Jurisdiction," Social Transformations in Chinese Societies (2020).

${ }^{54}$ Carroll, A Concise History of Hong Kong, 177.

${ }^{55}$ Cradock, Experiences of China, 167.

${ }^{56}$ Lui, "'Flying MPs' and Political Change in a Colonial Setting." 
Hong Kong to the modernization of China and promised to plan some cargo facilities for exclusively serving China's shipping business as an "exceptional arrangement" 57 . With this opportunity, MacLehose also raised the land lease problem. MacLehose's government perceived a message that Wang "was advising us to wait until the political and economic scene in China, and in Guangdong in particular, had stabilised further". Wang also suggested having more investments on both sides of the border could help assurances. MacLehose then asked "whether 'investment' included 'real estate", and Wang replied, "it included both, and both in the New Territories and on Hong Kong Island". MacLehose wanted to keep what had been discussed confidential and did not wish the members of the Councils would know anything about this meeting, and Wang agreed. In December, $\mathrm{Xi}$ Zhongxun, the Chairman of Guangdong Revolutionary Committee, visited Hong Kong and, regarding the land lease problem, "appeared to be following the same line of thought as that of Wang Kuang" ${ }^{58}$. It is noteworthy that the Chinese state is internally complex and contested, and these speeches from the local cadres might not necessarily reflect the mind of the central leadership but the interests of the local forces who strived for better performance amidst the economic reform. Nevertheless, these exchanges encouraged MacLehose to continue his task. The above political context is significant for explaining scalar politics in planning TSW after MacLehose had received the development proposal in January 1980, to which I now turn.

\section{Scalar politics of planning}

In this section, I report an analysis of the scalar politics by which I argue that, as discussed, the new town planning process was an exercise of various strategies adopted by different actors, under the conditions of imperfect information and shifting power relations, who attempted to link up the territorial events to specific categories of scale for realizing their respective goals and visions. In what follows, I begin with the territorial history of TSW, documenting how the developers obtained the right to hold the land and why they chose this piece of land. Then, I move on to report how the governments of Hong Kong, Britain and China reacted to the consortium's new town proposal. It is situated within the aforementioned urban and

\footnotetext{
57 'Record of Conversation at a Dinner at Government House on 1st November 1979', FCO40/1061: Future of Hong Kong: New Territories leases (Part D). 1979.

5813 December 1979, D Wilson to R Clift, FCO40/1061. Richard Clift was the Head of Hong Kong Department in FCO.
} 
political contexts of the colony's future. These contexts were full of uncertainty, as each side knew little about others. The intention of each subtle act by one was unknown to other involved actors, so the actors wanted to tease out what others were thinking about at multiple scales. Yet, the story will reveal that their attempts during the negotiations were simply a contingent sequence of misunderstandings, and they failed to correctly guess the unknown, which somehow led to the making of urban plans.

As will be seen, this development proposal at the local scale had been associated with the international scale, where London treated it as a rehearsal of the diplomatic negotiations over their colonial governance which might possibly happen. Soon after London knew that the participation of Beijing was less than minor, and that the local developers had exaggerated their self-claimed capacity as representing the interests of Beijing, Britain realized it was impossible to resolve the land lease problem with this episode. But MacLehose's government did not give up this proposal because they believed TSW could be an unusual opportunity to facilitate regional development in South China and thus favor China's economic reform, which could in turn offer advantages to sustaining the colonial governance as it was the goal of his tenure. These dynamics at multiple scales resulted in legal changes, infrastructural development strategies and a new town urban plan at the local scale.

\section{The land of Tin Shui Wai}

Before it was named Tin Shui Wai, the area was a muddy embayment named Ha Tsuen Wan. It became part of the new grant lots owned and managed by the colonial government because the Tang clan, the indigenous villagers who settled nearby and had been practicing oyster farming there, did not claim their customary rights to this wetland during the land survey at the beginning of the Twentieth Century. Villagers did not declare the land titles because of taxation concern ${ }^{59}$ and their trust in the validity of their customary land rights from the Qing Empire ${ }^{60}$. In the 1910s, the Chiu family moved from the unstable South China to Hong Kong and proposed to reclaim this 500-hectare wetland. The government approved and leased them the land, considering it as an opportunity to weaken the Tang clan

\footnotetext{
${ }^{59}$ James Hayes, The Great Difference: Hong Kong's New Territories and Its People, 18982004 (Hong Kong: Hong Kong University Press, 2006).

${ }^{60}$ Patrick H. Hase, "The Traditional Land Law of the New Territories, Before and After 1899," in Colonial Administration and Land Reform in East Asia, Ed. Sui-Wai Cheung (Routledge, 2017), 89-102.
} 
who had fiercely opposed the colonial government when it was taking over the leased area ${ }^{61}$. This was how the government utilized the leasehold system to restrain the local forces. The Chiu family named the land Tin Shui Wai, where large-scale rice production and commercial fishponds took place successively until the $1970 \mathrm{~s}^{62}$.

As mentioned, the Special Committee recommended to develop the areas near TSW, i.e. Fung Kong Tsuen and Lau Fau Shan. The report disclosed that the Public Works Department consultants were already conducting planning studies there as part of the Yuen Long new town development project. This internal information was made publicly known with the publication of this report, implying the government might invest to provide infrastructure and public works in this area soon. This reported hinted the developers who were eager to tease out the government's plan of urban development. Cheung Kong Holdings, established by Li Ka-Shing in 1971, also followed this report and deployed its resources. Cheung Kong had been acquiring land in the New Territories and started to place their hands on TSW in 1978. It took around two years to purchase more-thanhalf of shares of Luen Tak Company which "owns some 52 million sq. ft. of agricultural land at Tin Shui Wai, Yuen Long. The area thus attributable to the Group is about 25 million sq. $\mathrm{ft}$. Preliminary plans for the development of this site are being made and the Group believes that this project has considerable potential" 63 . Cheung Kong had an ambitious plan about TSW as a map in their annual report showed residential, commercial and industrial sites shall be developed there. Meanwhile, a shareholder of Luen Tak challenged Cheung Kong's purchase, but the court decision in 1978 ruled that the purchase was legal ${ }^{64}$. This prompted Cheung Kong to invite partners to this project, including Wheelock and Trafalgar.

\footnotetext{
${ }^{61}$ Armando M. da Silva, "Native Management of Coastal Wetlands in Hong Kong: A Case Study of Wetland Change at Tin Shui Wai Agricultural Lot, New Territories" (Department of Geography, University of Hawaii, 1977); Peter Wesley-Smith, Unequal Treaty, 1898-1997: China, Great Britain, and Hong Kong's New Territories (Hong Kong ; New York: Oxford University Press, 1998).

${ }^{62}$ Sidney C.H. Cheung, "The Politics of Wetlandscape: Fishery Heritage and Natural Conservation in Hong Kong," International Journal of Heritage Studies 17, no. 1 (2011): $36-45$.

${ }^{63}$ Cheung Kong Annual Report 1978.

${ }^{64}$ [1978]HCA1984: Chiu Butt York v. Chiu Kwok Lim And Others. 26 October 1978.
} 
Moreover, Cheung Kong in 1979 invited a partner that no one could have ever expected - CRC, which was established by the Chinese Communist Party in pre-war Hong Kong65. A proportion of shares of Luen Tak Company was sold to CRC in 197966. It was the first time for CRC to step into the real estate market. Four developers then formed a consortium named Mightycity, in which CRC was the leading company holding $51 \%$ of shares. Following some further transactions and legal procedures, Mightycity successfully obtained the ownership of Luen Tak Company at a court-ordered auction and, thus, became the sole landholder of TSW. The land was de jure still under a lease between the colonial government and Luen Tak, but after Luen Tak's composition was changed, Mightycity became the de facto landholder. As the land lease problem became a pressing concern, the participation of a Chinese-state owned enterprise in a project in the New Territories attracted the colonial government and London's attention. When David Wilson, the political adviser to the Governor, reported this to London ${ }^{67}$, he characterized the auction as "essentially a legal technicality" and labelled the consortium as "a powerful grouping" 68 .

The land of TSW had three favorable conditions for development. Firstly, geomorphologically it was a flat area, and the 1977 report hinted that the government was planning to develop the surrounding areas. Secondly, the land was held by a single lessee, which made it easier for the developers to obtain. The consortium started to purchase Luen Tak's shares by approaching an intermediary agent surnamed Chiu among the shareholders $^{69}$, and it was only able to acquire $93 \%$ of the shares, but the law allowed it to seek the court's order for a public auction of the remaining shares ${ }^{70}$. Thirdly, being neither tso nor tong land held by the indigenous villagers, TSW's legal status was merely subject to the government lease. The complexities of the customary land system, entailing the legal

\footnotetext{
${ }^{65} \mathrm{Wu}$, Red China Resources Company.

${ }^{66}$ Cheung Kong Interim Report and Annual Report 1979.

${ }^{67}$ David Wilson became Hong Kong Governor in 1987.

${ }^{68} 29$ September 1980, Wilson to Clift, "Tin Shui Wai”, FCO40/1163: Future of Hong Kong (Part B). 1980.

69 [1980]HKCFI17: Chiu Butt York v. Chiu Kwok Lim And Others; HCA4305/1979. 7 July 1980.

70 "Four Groups Cooperate to Build New Town in Tin Shui Wai in Twelve Years" (trans.), Kung Sheung Daily News, 23 September 1980; "Thousands of Acres of Land in Tin Shui Wai Sold for \$600 Million” (trans.), Ta Kung Pao, 23 September 1980.
} 
requirement of obtaining agreement from every single manager of the village community and the cultural concern about Fung Shui, were avoided.

\section{Consideration began at the local scale}

After informally expressing the development intention to the Secretary for the New Territories in late 1979, the consortium officially sought an approval for this new town proposal in 1980. The government felt that "the consortium is very anxious to cooperate with Government"71. After some exploratory meetings, the Executive Council discussed it on 20 May 1980, and then continued on 7 July 1981 and 4 May 1982, and drafted the agreement to be signed with Mightycity on 18 May 1982.

For the government, the proposed development did not violate the overall planning strategy because TSW "lies adjacent to one of the areas selected for study by the Special Committee on Land Production" [emphasis added] ${ }^{72}$. Involving the private sector could help solve the land shortage problem, so "a decision on Tin Shui Wai cannot be so easily be [sic] postponed"73. Director of New Territories Development commented that "Tin Shui Wai area offers the quickest and probably the cheapest opportunity for land production which is presently available in the New Territories"74. Thus, the government urged the importance of responding to the developers as soon as possible.

What rendered the proposal apparently complex was the involvement of the private developer with Chinese state background as the largest shareholder in the consortium at this politically critical moment after MacLehose's Beijing visit. As the consortium already leaked their proposal to the general public through mass media, the government interpreted this might raise political concerns. It is noteworthy that the government conversely raised the land lease problem to the consortium. The developers would only have around ten years to sell the property, so the government asked "how they propose to deal with this question. They have not yet been prepared to give an answer, but it is not considered that the decision on whether permission should be given to develop should be linked to their

718 May 1980, "Proposed Development of DD 126 LOT 665 Tin Shui Wai", XCC(80)67, HKRS261-6-1: Executive Council Papers (Secret \& Confidential) For Half Year Ending 30th June 1981. 1981.

${ }^{72}$ Ibid.

${ }^{73}$ Ibid.

${ }^{74}$ Ibid. 
answer"75. The Executive Council decided that the government would cooperate fully in the development study.

\section{Britain brought the plan to the international scale}

On the surface, the Executive Council seemed to have downplayed the political issues implied by the involvement of the Chinese red capital. But London and MacLehose indeed perceived the development proposal as a political move and regarded it as an opportunity to achieve their colonial goal, which was not made known to the Executive Council. MacLehose was often reluctant to disclose the politically sensitive information to the Legislative and Executive Councils ${ }^{76}$. The political concern was clear when David Wilson wrote, TSW "is probably the largest area of developable land in the New Territories under single ownership", and "[w]e know much less than I would wish about the reasons behind the involvement of China Resources in this land deal". Yet, Wilson as an experienced diplomat on Chinese affairs suggested that the evidence "tends to suggest that China Resources are in it purely to make money. They may not even have considered the political implication"77.

My following analysis shows the later reaction from the Chinese state affirmed Wilson's opinion. But the local developers in the consortium, who self-claimed as CRC's representatives, misguided Britain's action. John $\mathrm{Wu}$ of Trafalgar Holdings, who was the only contact person between the consortium and the government, made two suggestions to the government. Firstly, the payment of land premiums involved in land use change should be spread over twenty years which would go beyond 1997. Secondly, there was no need to put the usual clause about the expiry date on the land lease because the consortium believed the status quo of Hong Kong would be maintained after 1997. For Wilson, these two "interesting" suggestions were unanticipated, and he requested London to study their implications ${ }^{78}$. Although $\mathrm{Wu}$ self-claimed to be instructed by CRC, Wilson did not fully trust him because this could not be verified and, more importantly, he could

\footnotetext{
${ }^{75}$ Ibid.

${ }^{76}$ Chung, Hong Kong's Journey to Reunification.

7725 January 1980, Wilson to Clift, "China Resources Purchase of Land in Hong Kong”, FCO40/1162: Future of Hong Kong (Part A). 1980.

785 June 1980, Wilson to Clift, "China Resources Involvement in the New Territories: Tin Shui Wai”, FCO40/1162.
} 
not know "whether China Resources have any higher authority for what they are saying"79.

London did not put their heart at ease. London made clear, while land premiums and land use change are "a matter for the Executive Council at the local scale", the political implications of the land lease concerned London $^{80}$. Edward Youde, the then Deputy Under-Secretary for Asia and the Far East, alerted MacLehose to the significance of 1982 due to the fifteenyear confidence crisis, and he should "use concrete cases (eg Tin Shui Wai) to build up an arrangement which would allow for land leases to run beyond $1997 " 81$.

Around that time, some local businessmen proposed to locate the new airport inside China. Both MacLehose and London suspected this proposal was endorsed by Beijing and were interested to see how Beijing was thinking about this. After Shenzhen was designated as a Special Economic Zone in 1979, London recognized an "evident Chinese policy of encouraging eventual 'symbiosis' of Hong Kong with southern Guangdong, through the development of industry etc around Shumchun and, perhaps, such projects as the China Resources-owned new town at Tin Shui Wai in the New Territories. We still need to calculate our attitude to such a process" 82 [emphasis added]. London instructed MacLehose's government to consult them before any liaising with the Chinese government unless issues are "purely technical" 83.

Thus far, London did not directly exchange with the Chinese leaders, and MacLehose's government also did not do so with CRC. When Lord Carrington, the Foreign Secretary, was planning to visit Beijing in March 1981, MacLehose suggested to raise TSW and land lease problem, and "if Tin Shui Wai leases were to be discussed in Peking, the project as a whole

\footnotetext{
${ }^{79}$ Ibid.

8027 October 1980, Orr to Peirce, “Tin Shui Wai”, FCO40/1164: Future of Hong Kong (Part C). 1980.

8126 November 1980, Youde to MacLehose, "Future of Hong Kong”, FCO40/1164.

${ }^{82} 11$ September 1980, MacLehose to Clift, "Replacement Airport for Hong Kong and the Future of Hong Kong”, FCO40/1181: Possible New Airport for Hong Kong. 1980.

8330 September 1980, Donald to Clift, "Replacement Airport for Kai Tak", FCO40/1181.
} 
should have been approved by ExCo" ${ }^{84}$. But Britain did not need to wait until Carrington's visit because of a dramatic development. After almost a year of paper talk, MacLehose's government finally knew about China's attitude through Edmund Lau, the General Manager of the Hongkong and Yaumati Ferry Company, who talked to Liao Chengzhih in Beijing in December 1980. Liao was "annoyed" by the involvement of CRC in TSW because CRC did not consult the Chinese leadership through Xinhua on this subject at all. Liao hoped the colonial government would not issue a beyond1997 land lease ${ }^{85}$.

This unexpected discovery prompted Britain to reformulate their strategy. Wilson, for the first time, talked to the Xinhua official about TSW. Li Jusheng, Xinhua's Second Director, “denied that China Resources either had authority to ask for a special kind of lease or that they had done so" 86 . This had somehow ended Britain's internal discussion. As Wilson remarked, "at the political level, the Chinese do not at present wish to use this opportunity to deal with the leases issue in an indirect manner". An FCO official made a hand-written comment on Wilson's letter that " $[\mathrm{t}]$ his is discouraging". CRC was only motivated by the relatively low land cost in $\mathrm{TSW}^{87}$. Perhaps what was more shocking was Li's viewpoints about Hong Kong. Li said, although China denied the "unequal treaties", they constituted the present reality of Hong Kong. And, although CRC was a Chinese state enterprise, it operated as a company in accordance with local regulations, so it respects the legal framework of Hong Kong. Li suggested that " $[\mathrm{t}]$ he 'large questions' would certainly have to be discussed at some time and would be discussed. But the time was too early for this". TSW was a "small question", and Li hoped the colonial government not to use this to deal with the larger question. Li further criticized that "the third party", which conceivably refers to the consortium, "must have misrepresented the position".

Lu Ping, a key Chinese diplomat on Hong Kong affairs, even commented it was "the British Fantasy" to solve the land lease problem by

\footnotetext{
8429 November 1980, "Meeting between The Governor and Mr Richard Clift: 29 November 1980", FCO40/1164.

${ }^{85} 17$ January 1981, Wilson to Clift, "Tin Shui Wai”, FCO40/1286: Future of Hong Kong (Part A). 1981.

${ }^{86}$ Ibid.

8715 January 1981, Political Adviser's Office, "Record of a Discussion on Tin Shui Wai in the PA's Office on 14 January, 1981", FCO40/1286.
} 
developing TSW, and the Chinese leadership was angry about CRC's unpermitted investment, "you cannot take this land even if it was much cheaper because this concerns our basic stance" 88 . The archives of CRC also prove that they eventually reported the proposal to Beijing in late-December 1980, which had then been challenged ${ }^{89}$. Probably for this reason, after Li's meeting with Wilson, CRC for the very first time proactively sought a meeting with the colonial government in January 1981. CRC clarified that "they wished to develop the area in co-operation, and in accordance with the policies of the Hong Kong Government" and "had not thought about the leases aspect". CRC also emphasized that TSW was a normal project, and they were willing to follow the normal practice of the government ${ }^{90}$. In short, Wu's suggestion on beyond-1997 leases was not backed by the Chinese state. Ironically, Wu went to Beijing with a hope to meet Liao about this matter, but Liao did not entertain him in person. When London felt "these reflect the wishful thinking and fertile imagination of Hong Kong Chinese" ${ }^{91}$, Wilson commented that John $\mathrm{Wu}$ had "an over-optimistic interpretation of Chinese reaction", and thus they should consider lease arrangement only if the suggestion "came from or through an official Chinese organisation" 92 .

After treating it at the international scale, London decided to rather tie back the local scale to TSW. While it was being handled by London, MacLehose clearly did not really have a say. Britain was obviously too optimistic and thought there was political significance about the land lease problem behind it. As the relevance to the land lease problem had been clarified, London instructed MacLehose to follow their normal procedures to process the proposal unless China were to have further moves. The urgency to approve the project before the Foreign Secretary's visit to Beijing did not exist anymore. But TSW continued to be political because MacLehose tied the regional scale to this project.

\section{Spatial integration with Shenzhen at the regional scale}

MacLehose wanted to advance Hong Kong to a superior British colony which benefits China. He did not forgo the opportunity to favor China by

\footnotetext{
${ }^{88}$ Lu, Ping Lu's Oral History about the Reunification of Hong Kong, 8.

${ }^{89} \mathrm{Wu}$, Red China Resources Company.

9015 January 1981, Political Adviser's Office, "Record of a Discussion on Tin Shui Wai in the PA's Office on 14 January, 1981", FCO40/1286.

9110 February 1981, Donald to Clift, FCO40/1286.

9223 February 1981, Wilson to Clift, "Tin Shui Wai”, FCO40/1286.
} 
contributing TSW to the Pearl River Delta at a regional scale, offering economic and political advantages to Britain. As reported to the Executive Council on 7 July 1981, the development study proposed to develop TSW in three phases over 18 years, including residential and industrial development ${ }^{93}$.

MacLehose's government was more than willing to cooperate with the developers. To reduce public works' burden, while receiving land premium, government's consultant proposed to grant land of equivalent value in the existing built area and retain the land of TSW as a land bank. But MacLehose's government opposed because of political advantages from "having a major developer with the backing of the China Resources Company involved in a large-scale, long-term project in the New Territories"94. Although the government firmly stated that "it is known that China Resources participation is motivated entirely by commercial rather than by political reasons" [emphasis added] ${ }^{95}$, approving such a proposal "would demonstrate the practical advantages of combining the resources of Government and the private sector" 96 . The government concluded that such a cooperation with CRC can tell the society that the government was able to work with Chinese-related organizations.

For this reason, the government insisted to follow the consortium's proposal to allocate part of TSW for private development, while the government would pay for the public works that connect to TSW and for resuming land for public housing and land bank. This significantly rejects the myth which wrongly perceived the land resumption as a sudden and inevitable decision to rescue CRC from a slump. The fact is that the government from the very beginning had been spending effort to persuade the consortium for allowing it to participate in the project to gain political advantages.

In MacLehose's consideration, the political advantages were not only about the government's capacity to cooperate with China, but also about the ways of supporting China's economic reform. To understand the latter, MacLehose considered how the TSW proposal and potential cross-border

9324 June 1981, "Proposed Development of DD 126 LOT 665 Tin Shui Wai", XCC(81)76, HKRS261-9-1: Executive Council Papers (Secret \& Confidential) For Half Year Ending 31st December 1981. 1981.

${ }^{94}$ Ibid.

${ }^{95}$ Ibid.

${ }^{96}$ Ibid. 
development could altogether generate a greater help to facilitate the flow of goods, people and money between Hong Kong and China, which was believed to be a necessary step to secure Britain's interests in Hong Kong. Thus, regional development strategy also concerned MacLehose's government to consider the transport infrastructural demands within the territory and with China. The existing road-based traffic corridor in the East (Shatin-Taipo-Lowu corridor) was considered inadequate. There was a proposal to build a new airport, though some local businessmen suggested locating it in China as mentioned in the previous section, the government preferred to construct it in Lantau Island, the largest and undeveloped island in Hong Kong located at the mouth of the Pearl River. For better access from the Kwai Chung container port and the proposed airport in Lantau to China, the government was planning a Western Corridor. For the government, the developers submitted a timely proposal because "the emphasis of development should be shifted to areas served by improved western corridor routes which would, in turn, provide improved traffic links to China" ${ }^{97}$. TSW spatially acted as a transportation hub for this Western Corridor. It also served the water-based traffic with the planning of a new port in Tuen Mun, currently River Trade Terminal, serving South China along the Pearl River. The first urban plan of TSW in 1983 allocated a considerable proportion of industrial land as storage and warehouse ${ }^{98}$. If TSW's development followed this plan, the Terminal might have a higher usage rate now ${ }^{99}$. As part of the Western Corridor strategy, TSW was planned as a hub between China and the world, forming the network between the nodes at the factories in South China, the trading companies in Hong Kong, the customers abroad, the proposed airport, the container ports and the warehouses. In short, as MacLehose's government suggested, "multiple benefit [sic] from unavoidable investment in infrastructure" would be achieved ${ }^{100}$.

As noted in the second section, limited resources in public finance had been a key constraint in urban development in Hong Kong. Public housing provision and new town development in the 1970s have "pulled

\footnotetext{
${ }^{97}$ Ibid.

${ }^{98}$ Shankland Cox Partnership and Binnie \& Partners (Hong Kong), Tin Shui Wai Urban Development: Master Development Plan (Hong Kong: New Territories Development Branch, Hong Kong Government, 1983). The plan is publicly accessible at https://digitalrepository.lib.hku.hk/catalog/zw130608q.

${ }^{99}$ Due to its low usage rate, Hong Kong government proposed to redevelop the terminal in 2018 during the "Land Debate".
}

${ }^{100}$ XCC(81)76, HKRS261-9-1. 
ahead of the necessary complementary improvements to transport systems" ${ }^{101}$. But the government never thought about forgoing TSW. Instead, TSW "may have to be given continuing priority, possibly at the expense of other more urgent or deserving undertakings" ${ }^{102}$. Although the government worked to liaison with the consortium, how the government should prepare for the public financial accounts for this unavoidable infrastructural investment in TSW became a challenge for John Bremridge, who became the Financial Secretary in June $1981^{103}$.

In view of rising public works demand and inflationary pressure on the construction industry, Bremridge had to better manage the public works programme. The Legislative Council approved Bremridge's proposal to establish a Capital Works Reserve Fund (CWRF) with effect from 1 April $1982^{104}$. The principles were to abandon the "annuality" approach and to adopt a project-based approach to finance the public works. CWRF is funded by transferring a proportion of money from both the general recurrent revenue and land sales in the public finance accounts ${ }^{105}$. Judge Godfrey in his judgement of a dispute about TSW declared that introducing CWRF and relevant procedural changes were "central to the history of the reclamation of the land at Tin Shui Wai" ${ }^{106 .}$

\footnotetext{
${ }^{101}$ Ibid.

102 Ibid.

103 "Tin Shui Wai New Town Plan to be Examined by the Executive Council" (trans.), Kung Sheung Evening News, 21 May 1981.

104 "UMELCO Office Brief on Draft Estimates of Expenditure 1982-83", No.91/8182, HKRS618-1-631: 1982 Budget Debates. 1982.

${ }^{105}$ FC(B.177), "Financing of the Public Works Programme and Land Acquisition", Hong Kong Legislative Council. See also 20 January 1982, Hong Kong Hansard. In Bremridge's original design, the money in CWRF should be strictly controlled, and the interest earned should be put back to the general account. This is because the original design of CWRF was only for better project management, and it was thus important to ensure CWRF would only contain the amount of money that was approved by the Legislative Council to pay for the public works. In other words, the capital works must not be invested at the expense of the social needs which would be covered by the general account. These principles underpinning CWRF have been thoroughly abandoned by Beijing in the 1984 Sino-British Joint Declaration, see also Yip, "Hong Kong as a property jurisdiction."
}

106 [1992]HKCFI96. 


\section{Large question at the international scale, small question at the local scale}

In May 1982, a few days before Edward Youde took over MacLehose's office, the Executive Council approved the agreement ${ }^{107}$. The managerial officials of CRC signed the agreement on behalf of Mightycity on 29 July 1982. The agreement followed what MacLehose's government had been proposing since the beginning. After the government resumes the land from Mightycity, the Northern part would be retained as a land bank and the Southern part would be developed; in which a part would be leased back to Mightycity for private development, and other parts would be public housing and social facilities. Interestingly, the government assured the public that TSW had nothing to deal with politics and the Chinese government and the Guangdong Province were not consulted ${ }^{108}$.

Nevertheless, TSW still has its political significance as revealed by two observations. Firstly, the expiry date of land lease in 1997 was not publicly disclosed, although the government re-leased the land to Mightycity on a 99-year lease term commencing in 1898 and the development phases would go beyond 1997. The government might not want to further trigger the confidence crisis. As Judge Godfrey commented that

[o]ne important matter of background, not touched on in the press release, does however need to be added; that is that, in 1982, noone could be certain what rights would subsist in land in the New Territories after 1997. (It was generally believed in Hong Kong in 1982 that rights in land subsisting in 1997 would, in one way or another, be extended so as to continue after 1997. But it was to be 1984 before the uncertainty was resolved.) ${ }^{109}$.

Secondly, in August 1982, CRC wrote to Beijing that "after our negotiation with the British Hong Kong government over the land development of Tin Shui Wai for more than one and a half year, with several twists and turns,

\footnotetext{
107 "Minutes of the 16th Meeting of the Executive Council of Hong Kong Held in the Council Chamber on Tuesday, 4th May 1982", M(82)16, HKRS261-11-1: Executive Council Papers (Secret \& Confidential) For Half Year Ending 30th June 1982. 1982; "Minutes of the 18th Meeting of the Executive Council of Hong Kong Held in the Council Chamber on Tuesday, 18th May 1982", M(82)18, HKRS261$11-1$.

108 "Government Spent \$2.2 Billion to Resume Tin Shui Wai" (trans.), Kung Sheung Daily News, 30 July 1982.

109 [1992]HKCFI96: Tin Shui Wai Development LTD v. Attorney General; HCCT5/1987. 30 September 1992.
} 
both parties finally signed the agreement on $29^{\text {th }}$ July" ${ }^{110}$. CRC trickily emphasized that the area for private development would be serviced land which the government would grant to them free of charge and bear the infrastructural cost ${ }^{111}$. This might have misled Beijing because the land was not free of charge, though the land premium was deducted from the government's payment. CRC also justified that their involvement in TSW had put the investors' hearts at ease.

Whereas TSW was a small question about local development, it was strongly associated with the large question between Britain and China. This explains why the deal must be reached in July 1982, two months before Thatcher's Beijing visit. As the CRC archives documented, Thatcher told Deng that "the question of Tin Shui Wai has been solved" before the SinoBritish negotiations started.

\section{Conclusion}

This article explains why the colonial government had to resume TSW and develop it in a partnership with the consortium. It debunks the "Tin Shui Wai Myth" which is shown to be a time-capsule account that detaches the vital scalar processes from the facts. Through the lens of scalar politics, the account goes beyond the static conception of scale in analyzing the sociospatial dynamics of new town planning and development. While legal arrangements and political reactions reconfigured and transformed the inter-scalar relations, the land lease, which had been enacted, modified, transacted and contested, mattered in shaping spatiality and power relations. These power relations created the scalar politics, shifting between the governor and London, between the government and developers, between red capital and Beijing, and between Britain and China. As a result of the scalar politics, the land transaction in 1982 had nothing to deal with market slump.

This planning episode adds new knowledge to this chapter of "the gap period" between those two critical moments in the story of Hong Kong. Firstly, this case study reveals a spatial dimension of diplomatic relations. Diplomatic negotiations are not only high-level interactions between state powers about territorial disputes, political agenda or ideological conflicts, but could also have impacts on, and being influenced by, the ongoing urban

\footnotetext{
${ }^{110}$ Wu, Red China Resources Company, 436-37. 16 August 1982, CRC(82)No.88. My translation.

${ }^{111}$ Ibid.
} 
transformation within the territory. Secondly, it enriches our understanding of the local politics of colonial governance, especially the distance between the governor and the local people. While some in Hong Kong might feel nostalgia for the colonial days with improved living quality and rapid economic growth, this case demonstrates how the colonial authority's decision-making process had foregrounded their self-interest, excluding both the public and even the closely related members in the Councils from knowing the real political calculation and plans. The local people could play central roles in neither the planning process of TSW nor the Sino-British Negotiations. Thirdly, the case of TSW sheds light on the political economy of Hong Kong and China in the late 1970s and the early 1980s. At the beginning of the economic reform, both sides knew very little about another across the border, giving rise to many fantasies of securing interests and earning from the business environment. Only through real interactions and confrontations, they could learn more about each other before adopting the right strategy to realize their desired objectives.

What motivated the developers to invite CRC deserves a remark. Albeit staying in the background, Li Ka-Shing and other developers, I speculate, wanted to assess the investment environment in the 1980s. Undoubtedly these people later became co-opted into Beijing's united front and are still influential in the urban politics of Hong Kong. But, before that, they were feeling the full brunt of the lease problem because they had been hoarding land in the New Territories. While China had no idea about the problem at all, and Britain was seemingly optimistic to rely on the treaties, the perception that both China and Britain remained silent alerted the local capitalists to the great uncertainty. As it was clear that CRC has a strong background of the Chinese state and wanted to make money, these developers attempted to take advantage of CRC to tease out possible solutions. They self-claimed to be the representative of CRC. CRC enjoyed favorable conditions that Cheung Kong promised CRC can share the profit without taking responsibility for the financial cost. Consequently, CRC, whose decision originally annoyed Beijing, withdrew from the project after the sovereignty transfer, when Hong Kong's confidence crisis was settled on the surface.

Planning failures cannot explain TSW's problems. The 1983 master plan of its southern part included a balanced land uses pattern which could facilitate a reasonable urban life. But urban planning and development are full of uncertainties. The later development of TSW was complicated by its historical geography. For example, border disputes between China and 
Hong Kong in the late 1980s delayed the supply of reclamation materials ${ }^{112}$, decreasing industrial demand due to rapid industrial relocation to mainland China led to modification of the plan, and a very large proportion of land bank in the northern part was used to build public housing without adequate provision of social facilities because of the altered political agenda of housing provision after the sovereignty transfer in 1997.

TSW was the first time for the colonial government to consider the factor of benefiting China in plan-making, which is now normalized in Hong Kong under the new constitutional order of "One Country, Two Systems". Recent debates on new town development in Hong Kong frequently aroused fears about creating another TSW based on the problematic myth. As the government under Chinese sovereignty agrees and blames the colonial government for TSW's problems, it can readily be acquitted of those charges against the controversies of regional integration with mainland China by assuring a good plan-making process. In view of the current controversies about regional development and integration between mainland China and Hong Kong, debates should be politicized to decipher what lies behind urban plans. This is to ask through what processes, and for what reasons, land injustice in Hong Kong was produced and is perpetuated (for example, the tremendous reform of CWRF during the negotiations) ${ }^{113}$. Likewise, scrutinizing the underlying stories is necessary for analyses of urban plans, everywhere in the world, in urban planning research.

\footnotetext{
112 Ka-Lam Pang and Ha-Chi Yeung, "When Tin Shui Wai Met Hong Kong's Future [當天水圍遇上香港前途],” City Magazine, September 2017.

${ }^{113}$ Yip, "Hong Kong as a Property Jurisdiction."
} 